\section{Jurnal Mitra Pendidikan (JMP Online)}

URL : http://e-jurnalmitrapendidikan.com
JMP Online

Vol. 4, No. 8, 554-568

(C) 2020 Kresna BIP. e-ISSN 2550-0481 p-ISSN 2614-7254

\title{
MENINGKATKAN KEMAMPUAN GURU DALAM MEMBUAT PROGRAM REMIDIAL MELALUI PEMBINAAN GURU DENGAN DISKUSI KELOMPOK DI SDN TELOK JOLO 3 SEMESTER II TAHUN AJARAN 2018 / 2019
}

\author{
Muksin
}

SDN Telok Jolo 3

INFORMASI ARTIKEL

Dikirim : 22 Agustus 2020

Revisi pertama : 25 Agustus 2020

Diterima : 25 Agustus 2020

Tersedia online : 29 Agustus 2020

Kata Kunci: Kemampuan Guru, Membuat Program Remidial, Diskusi Kelompok

Email: muksinalatas979@gmail.com
ABSTRAK

Penelitian ini bertujuan untuk mengetahui upaya yang dilakukan oleh kepala sekolah dalam meningkatkan kemampuan guru dan mengetahui peningkatan kemampuan guru dalam membuat program remidial melalui pembinaan guru dengan diskusi kelompok di SDN Telok Jolo 3 Semester II Tahun Ajaran 2018 / 2019.

Lokasi penelitian ini dilakukan di SDN Telok Jolo 3 Kecamatan Sumber Barito Kabupaten Murung Raya Provinsi Kalimantan Tengah. Subjek penelitian ini adalah guru kelas yang berjumlah 5 orang. Penelitian ini dilaksanakan pada Semester II Tahun Ajaran 2018/2019, yang dimulai sejak bulan Januari sampai dengan Juni 2019.

Berdasarkan penelitian yang sudah dilakukan, didapatkan hasil kesimpulannya bahwa pada saat proses pelaksanaan kegiatan pembinaan yang dilakukan oleh kepala sekolah dinilai dapat meningkatkan kemampuan guru, hal tersebut dapat dilihat melalui hasil observasi yang dilakukan oleh peneliti meningkat secara signifikan mulai dari siklus I dengan hasil rata-rata cukup meningkat. Sehingga dapat disimpulkan bahwa adanya kegiatan pembinaan yang dilakukan oleh kepala sekolah dapat meningkatkan kemampuan guru dalam menyusun program remidial. 


\section{PENDAHULUAN \\ Latar Belakang}

Pendidikan adalah suatu hal yang sangat penting dan sangat berpengaruhdata kehidupan manusia. Pendidikan di Indonesia menjadi prioritas utama, karena mendapatkan penanganan yang khusus dari pemerintah pusat. Upaya inovasi pendidikan yang dilakukan pemerintah guna pendidikan di Indonesia mampu bersaing dengan dunia global. Hal ini dibuktikan dengan mengajukan pendidikan di Indonesia pemerintah berusaha keras untuk mewujudkannya.

Lewat pendidikan, seseorang dapat membentuk kepribadian yang lebih baik sesuai yang diinginkan. Seiring dengan meningkatnya kualitas pendidikan Indonesia akan memiliki sumber daya manusia yang berkualitas.Pendidikan merupakan sektor yang strategis untuk meningkatkan kualitas sumber daya manusia dan mencerdaskan kehidupan bangsa. Dalam Undang-Undang No. 20 Tahun 2003 tentang Sistem Pendidikan nasional dijelaskan Bahwa :

"Pendidikan adalah usaha sadar dan terencana untuk mewujudkan suasana belajar dan proses pembelajaran agar peserta didik secaraaktif mengembangkan potensi dirinya untuk memiliki kekuatan sepiritual, keagamaan, pengendalian diri, kepribadian, kecerdasan, akhlak mulia, serta keterampilan yang diperlukan dirinya, masyarakat, bangsa, dan Negara”.

Dalam rangka membantu peserta didik mencapai standar isi dan standar kompetensi lulusan, pelaksanaan atau proses pembelajaran perlu diusahakan agar interaktif, inspiratif, menyenangkan, menantang, memotivasi peserta didik untuk berpartisipasi aktif. Begitupun dalam masalah pembelajaran tidak dapat dipungkiri bahwa untuk mencapai tujuan dan prinsip-prinsip pembelajaran tersebut pasti dijumpai adanya peserta didik yang mengalami kesulitan atau masalah belajar. Untuk mengatasi masalah-masalah tersebut, setiap satuan pendidikan perlu menyelenggarakan program pembelajaran remedial atau perbaikan.

Jadi, Remedial Teaching merupakan layanan pendidikan yang diberikan kepada peserta didik untuk memperbaiki prestasi belajarnya sehingga mencapai kriteria ketuntasan yang ditetapkan. Untuk memahami konsep penyelenggaraan model pembelajaran remedial, terlebih dahulu perlu diperhatikan bahwa Kurikulum Tingkat Satuan Pendidikan (KTSP) yang diberlakukan berdasarkan Permendiknas 22, 23, 24 Tahun 2006 dan Permendiknas No. 6 Tahun 2007 menerapkan sistem pembelajaran berbasis kompetensi, sistem belajar tuntas, dan sistem pembelajaran yang memperhatikan perbedaan individual peserta didik.

Pelaksanaan pembelajaran berbasis kompetensi dan pembelajaran tuntas, di mulai dari penilaian kemampuan awal peserta didik terhadap kompetensi atau materi yang akan dipelajari. Kemudian dilaksanakan pembelajaran menggunakan macam-macam metode atau dengan berbagai macam media pembelajaran.

Di tengah pelaksanaan pembelajaran atau pada saat kegiatan pembelajaran sedang berlangsung, diadakan penilaian proses menggunakan berbagai teknik dan instrumen dengan tujuan untuk mengetahui kemajuan belajar serta seberapa jauh penguasaan peserta didik terhadap kompetensi yang telah atau sedang dipelajari. Pada akhir program pembelajaran, diadakan penilaian yang lebih formal berupa ulangan harian. Ulangan harian dimaksudkan untuk menentukan tingkat 
pencapaian belajar peserta didik, apakah seorang peserta didik gagal atau berhasil mencapai tingkat penguasaan tertentu yang telah dirumuskan pada saat pembelajaran direncanakan.

Upaya-upaya untuk meningkatkan kemampuan guru dalam membuat program remedial adalah melalui pembinaan guru. Menurut Hamzah (2016:169) mengemukakan bahwa pembinaan guru adalah serangkaian usaha bantuan kepada guru yang dilakukan oleh kepala sekolah, pengawas sekolah, penilik sekolah, serta pembina lainnya bertujuan untuk meningkatkan proses dan hasil belajar.

Berdasarkan observasi awal yang dilakukan di SDN Telok Jolo 3 tentang kemampuan guru dalam membuat program remidial melalui pembinaan guru dengan diskusi kelompok masih kurang maksimal, hasilnya guru masih belum sempurna dalam menyusun dan mengelola program remedial. Oleh karena itu perlu adanya peningkatan dalam membuat program remedial. Berdasarkan pemikiran di atas perlu segera dilakukan penelitian mengenai upaya meningkatakan kemampuan guru membuat program remedial melalui pembinaan guru dengan diskusi kelompok, maka peneliti membuat penelitian yang berjudul Meningkatkan Kemampuan Guru Dalam Membuat Program Remidial Melalui Pembinaan Guru Dengan Diskusi Kelompok di SDN Telok Jolo 3 Semester II Tahun Ajaran 2018 / 2019.

\section{Rumusan Masalah}

Berdasarkan latar belakang masalah diatas, maka rumusan masalah dalam penelitian ini adalah sebagai berikut :

1. Bagaimana upaya yang dilakukan oleh kepala sekolah dalam meningkatkan kemampuan guru dalam membuat program remidial melalui pembinaan guru dengan diskusi kelompok di SDN Telok Jolo 3 Semester II Tahun Ajaran 2018 / 2019?

2. Bagaiamana peningkatan kemampuan guru dalam membuat program remidial melalui pembinaan guru dengan diskusi kelompok di SDN Telok Jolo 3 Semester II Tahun Ajaran 2018 / 2019?

\section{Tujuan Penelitian}

Penelitian ini bertujuan untuk :

1. Untuk mengetahui upaya yang dilakukan oleh kepala sekolah dalam meningkatkan kemampuan guru dalam membuat program remidial melalui pembinaan guru dengan diskusi kelompok di SDN Telok Jolo 3 Semester II Tahun Ajaran 2018 / 2019.

2. Untuk mengetahui peningkatan kemampuan guru dalam membuat program remidial melalui pembinaan guru dengan diskusi kelompok di SDN Telok Jolo 3 Semester II Tahun Ajaran 2018 / 2019.

\section{KAJIAN PUSTAKA \\ Kemampuan Guru}

Dalam Kamus Besar Bahasa Indonesia kemampuan berasal dari kata mampu yang berarti kuasa (bisa, sanggup melakukan sesuatu). Kemudian kata 
mampu mendapatkan awalan ke- dan akhiran -an, sehingga kemampuan dapat diartikan sebagai kekuatan, kecakapan, kesanggupan (Depdikbud, 2008).

Menurut Shadily dalam Kartini Kartono (2010) kata kemampuan berasal dari bahasa inggris yaitu "competence" yang berarti "kemampuan". Jadi kemampuan identik dengan kompetensi, maka dalam hal ini peneliti akan menguraikan masalah kompetensi seorang guru. Kemajuan zaman semakin cepat maka guru dituntut dapat beradaptasi secara menyeluruh baik terhadap pelaksanaan pendidikan maupun keterampilan tertentu yang melingkupinya, di samping faktor kepribadian yang semakin mantap dan meyakinkan, maka perlu adanya kompetensi.

Kemampuan menurut Kunandar (2011) adalah suatu yang dimiliki oleh seseorang untuk melakukan tugas dan pekerjaan yang dibebankan kepadanya. Menurut Broker dan Stone dalam Cece Wijaya (2010) memberikan pengertian kemampuan guru adalah sebagai gambaran hakikat kualitatif dari perilaku guru atau tenaga kependidikan yang tampak sangat berarti.

Berdasarkan defenisi tersebut dapat penulis ambil kesimpulan bahwa kemampuan guru adalah potensi atau kesanggupan yang dikuasai guru untuk melakukan suatu aktifitas atau kegiatan.

\section{Program Remidial}

Dilihat dari arti katanya "remedial" berarti bersifat menyembuhkan, membetulkan atau membuat menjadi baik. Dengan demikian remedial teachingadalah suatu bentuk pengajaran yang bersifat membetulkan atau pengajaran yang membuat menjadi baik.

Good (dalam sukardi, 2008:228) menyatakan Class remedial is a specially selected groups of pupils in need of more intensive instruction insome area education than posibble in the reguler classroom, remidial kelas merupakan pengelompokan siswa, khusus yang dipilih memerlukan pembelajaran lebih pada mata pelajaran tertentu dari pada siswa dalam kelas biasa.

Sugihartono, dkk (2007:171) menyatakan bahwa remedial teaching merupakan kegiatan yang penting dalam keseluruhan program pembelajaran. Melalui remedial teaching guru membantu siswa dalam untuk mencapai tujuan pembelajaran secara optimal.

Menurut pengertian pada umumnya proses pengajaran bertujuan agar siswa dapat mencapai hasil belajar yang sebaik-baiknya, jika ternyata hasil belajar yang dicapai tidak memuaskan berarti siswa masih dianggap belum mencapai hasil belajar yang diharapkan sehingga masih diperlukan suatu proses pengajaran yang dapat membantu siswa agar terapai hasil belajar seperti yang diharapkan.

Dari ketiga pengertian yang dikemukakan para ahli diatas dapat disimpulkan bahwa remedial teachingadalah memberi harapan baik terhadap siswa yang mengalami kesulitan belajar agar siswa dapat mencapai hasil belajar yang diharapkan. Serta merupakan pembelajaran yang bersifat khusus dimana pembelajaran remedial baru dilaksanakan setelah mengetahui tingkat kesulitan belajar yang dialami siswa. 


\section{Tujuan Program Remidial}

Walkitri (dalam Sugihartono, dkk., 2007:173) tujuan remedial teaching dibagi menjadi dua yaitu tujuan secara umum dan tujuan secara khusus. Secara umum remedial teachingbertujuanuntuk membantu siswa mencapai hasil belajar sesuai dengan tujuan pembelajaran yang ditetapkan dalam kurikulum. Secara khusus tujuan remedial teachingadalah membantu siswa yang mengalami kesulitan belajar agar mencapai prestasi yang diharapkan melalui proses penyembuhan dalam aspek kepribadian atau dalam proses belajar mengajar.

Menurut Kustawan (2013:51) tujuan remedial teaching adalah sebagai berikut:

1. Setiap siswa mencapai kompetensi sesuai dengan tujuan yang ditetapkan.

2. Memahami kelebihan dan kekurangan kompetensi siswa, termasuk jenis dan sifat kesulitan yang dihadapinya

3. Memilih dan menggunakan fasilitas belajar yang tepat dan mengatasi hambatan yang menjadi latar belakang kesulitannya.

4. Mengubah atau memperbaiki cara belajar siswa yang lebih efektif dan efisien sesuai dengan karakteristiknya.

5. Agar siswa dapat mengembangkan sikap dan kebiasaan yang dapat memotivasi pencapaian hasil belajar yang lebih baik dan melaksanakan tugas belajar yang lebih baik juga.

Dari pemaparan para tokoh dapat disimpulkan bahwa remedial teachingmerupakan suatu program yang perlu dilakukan sesuai dengan kesulitan belajar yang siswa alami. Hal ini dilakukan dengan tujuan untuk membantu siswa yang mengalami kesulitan belajar siswa untuk mencapai tujuan pembelajaran yang telah ditentukan, melalui proses penyembuhan sesuai dengan karakteristik siswa.

\section{Fungsi Remedial Teaching}

Warkitri (dalam Sugihartono, dkk. 2007:173) menyatakan ada beberapa fungsi dalam remedial teachinguntuk membantu siswa yang mengalami kesulitan belajar, antara lain fungsi korektif, pemahaman, penyesuaian, pengayaan, akselerasi dan terapeutik.

1. Fungsi Korektif

Fungsi Korektif merupakan usaha untuk memperbaiki atau meninjau kembali sesuatu yang dianggap keliru. Dalam remedial teachingfungsi korektif dilakukan melalui perbaikan dalam proses pembelejaran. Proses pembelajarannya berkaitan dengan aspek perumusan tujuan, penggunaan metode mengajar, materi, alat peraga, cara belajar, evaluasi dan kondisi dari masing-masing siswa. Aspek-aspek tersebut harus ditinjau dalam mengadakan remedial teachingsehingga mampu membantu tercapainya pembelajaran yang optimal.

2. Fungsi Pemahaman

Fungsi pemahaman, dalam remedial teachingterjadi proses pemahaman terhadap pribadi siswa, baik dari guru, pembimbing maupun siswa itu sendiri. Guru berusaha membantu siswa untuk memahami dirinya dalam kesulitan, kelemahan dan kelebihan yang dimilikinya. Dengan bantuan ini diharapkan siswa dapatmelaksanakan tugas-tugas belajarnya dengan baik. 


\section{Fungsi Penyesuaian}

Melalui remedial teachingsiswa di bantuuntuk belajar sesuai dengan keadaan dan kemampuan yang dimilikinya sehingga tidak menjadi beban namun akan menjadi peluang memperoleh prestasi bagi siswa

4. Fungsi akselerasi

Fungsi akselerasi, dalam remedial teaching guru mempercepat pembelajaran dengan menambah frekuensi pertemuan dan materi pembelajarannya

5. Fungsi terapeutik

Fungsi terapeutik, terkandung dalam remedial teachingkarena secara langsung atau tak langsung berusaha menyembuhkan gangguan dan hambatan kepribadian siswa. Siswa yang mengalami kesulitan belajar kemungkinan dapat mengalami hambatan kepribadian, sehingga dengan membamtu mengatasi kesulitan belajarberarti mengatasi hambatan kepribadian begitu juga sebaliknya.

Dari fungsi-fungsi diatas dapat disimpulkan bahwa fungsi remedial teaching adalah membantu guru dalam mengatasi siswa yang mengalami kesulitan agar siswa bisa mencapai Kriteria Ketuntasan Minimal yangmenjadi tolak ukur keberhasilan belajar siswa.

\section{Pembinaan Guru}

Menurut Mitha Thoha Pembinaan adalah Suatu tindakan, proses, hasil, atau pernyataanyang lebih baik. Dalam hal ini menunjukkan adanya kemajuan, peningkatan pertumbuhan, evolusi atas berbagai kemungkinan, berkembang atau peningkatan atas sesuatu. Ada dua unsurdari definisi pembinaan yaitu:

1. Pembinaan itu bisa berupa suatu tindakan, proses, ataupernyataan tujuan, dan;

2. Pembinaan bisa menunjukan kepada perbaikan atas sesuatu.

Menurut Poerwadarmita (2012). Pembinaan adalah suatu usaha, tindakan dan kegiatan yang dilakukan secara berdaya guna berhasil guna untukmemperoleh hasil yang lebih baik.

Menurut Zakiyah Dradjat pembinaan adalah upaya pendidikan baik formal atau non formal yang dilaksanakan secara sadar, terencana, terarah dan bertanggung jawab dalam rangka memperkenalkan, menumbuhkan dan mengembangkan suatu dasar kepribadian yang seimbang dan selaras.Secara lebih luas, pembinaan dapat diartikan sebagai serangkaian upaya, pengendalian profesional terhadap semua unsur organisasi agar berfungsi sebagaimana mestinya sehingga dapat terlaksana secara efektif dan efisien.

Pembinaan guru berarti serangkaian usaha ataupun bantuan yang diberikan kepada guru. Terutama bantuan yang berwujud layanan profesional yang dilakukan oleh kepala sekolah, pengawas serta pembina lainnya untuk meningkatkan proses mengajar dan hasil belajar siswa.

Jadi, pengertian pembinaan guru yang telah disampaikan diatas adalah serangkaian bantuan yang berwujud layanan profesional agar dapat meningkatkan kualitas proses dan hasil belajar sehingga tujuan pendidikan yang direncanakan dapat tercapai. 


\section{Metode Diskusi}

Metode secara harfiah berarti cara. Dalam pemakaian yang umum, metode diartikan sebagai suatu cara atau prosedur yang dipakai untuk mencapai tujuan tertentu. Metode pembelajaran berarti cara-cara yang dipakai untuk menyajikan bahan pelajaran kepada pesertadidik untuk mencapai tujuan pembelajaran yang telah ditentukan.

Pengertian diskusi, metode pembelajaran merupakan suatu cara yang digunakan untuk mencapai tujuan pembelajaran. Dengan menggunakan metode diskusi dalam proses pembelajaran siswa dalam dengan bebas berkomunikasi dalam mengemukakan gagasan dan pendapat. Tujuan dari metode diskusi ini adalah siswa terdorong untuk berpartisipasi secara optimal, tanpa ada aturanaturan yang keras, namun tetap harus mengikuti etika yang telah ditetapkan (Sanjaya, 2010:12)

Salah satu keterampilan guru yang memegang posisi penting adalah keterampilan memilih metode pembelajaran. Pemilihan metode pembelajaran berkaitan langsung dengan usaha guru dalam menampilkanpengajaran sesuai dengan situasi dan kondisi, sehingga tujuan pembelajaran dapat tercapai secara optimal (Fathurrohman dan Sulistyorini, 2010: 55).

Dari beberapa pengertian di atas dapat disimpulkan bahwa yang dimaksud dengan metode diskusi adalah suatu cara penyampaian materi pembelajaran dengan jalan bertukar pikiran baik antara guru dengan siswa atau siswa dengan siswa. Selain itu metode diskusi menumbuhkan motivasi siswa untuk berpikir atau mengeluarkan pendapatnya sendiri dengan wawasan pengetahuan yang mampu mencari jawaban.

\section{METODE PENELITIAN}

\section{Lokasi, Subjek dan Waktu Penelitian}

Lokasi penelitian ini dilakukan di SDN Telok Jolo 3 yang berlamatkan di Jalan.Kenaga RT.I Tumbang Mulut Kecamatan Sumber Barito Kabupaten Murung Raya Provinsi Kalimantan Tengah. Subjek penelitian ini adalah guru kelas yang berjumlah 5 orang. Penelitian ini dilaksanakan pada Semester II Tahun Ajaran 2018/2019, yang dimulai sejak bulan Januari sampai dengan Maret 2019.

\section{Prosedur Penelitian}

Penelitian ini merupakan penelitian tindakan sekolah (School Action Research), karena penelitian dilakukan untuk memecahkan masalah proses pembelajaran di sekolah. Penelitian tindakan sekolah menurut Sukmadinata (2010:56) adalah penelitian yang diarahkan pada pemecahan masalah atau perbaikan. Guru-guru mengadakan pemecahan terhadap masalah-masalah yang dihadapi dalam kelasnya, kepala sekolah mengadakan perbaikan terhadap managemen di sekolahnya. Penelitian ini difokuskan pada perbaikan kualitas mengajar guru. Penelitian tindakan merupakan cara ilmiah yang sistematis dan bersifat siklus untuk mengkaji situasi sosial, memahami permasalahan, dan selanjutnya menemukan pengetahuan yang berupa tindakan untuk memperbaiki situasi sosial tersebut. (Sugiyono, 2014:697-698). 
Sebelum masuk pada tindakan siklus I dilakukan tindakan pendahuluan yang berupa identifikasi permasalahan atau refleksi pra-siklus. Penggambaran Siklus tahap-tahap penelitian tindakan sekolah dapat dilihat pada gambar berikut:

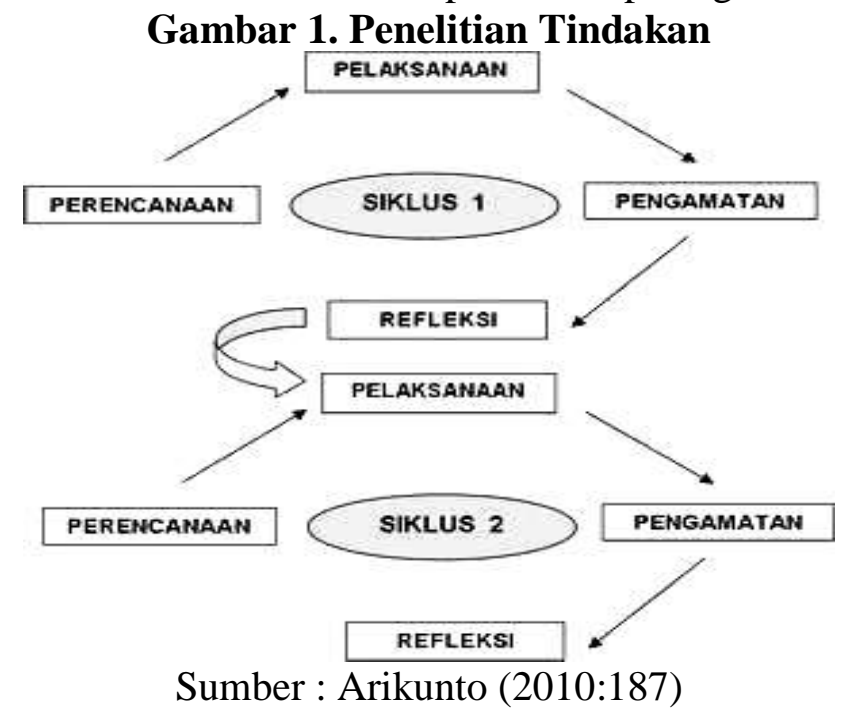

Arikunto, (2010:137) menjelasakan ada empat langkah pokok dalam Penelitian Tindakan Sekolah dalam satu siklus yaitu sebagai berikut:

1. Perencanaan tindakan

2. Pelaksanaan tindakan

3. Pengamatan (observasi)

4. Refleksi

Keempat langkah tersebut diatas direncanakan dalam 2 siklus dengan melibatkan. orang guru kelas SDN Telok Jolo 3.

\section{Teknik Pengumpulan Data}

Data dikumpulkan dalam penelitian ini dilakukan melalui beberapa teknik yang dapat dijelaskan sebagai berikut:

1. Teknik Observasi

Teknik observasi digunakan untuk memperoleh data langsung dari pelaksanaan aktivitas kegiatan yang sudah direncanakan berupa data nilai observasi kualitas pembuatan soal guru. Berikut merupakan istrumen kemampuan guru.

2. Teknik Dokumentasi

Teknik dokumentasi digunakan untuk memperoleh berbagai dokumen yang berupa data nama guru, nama observer, dan jadwal kegiatan pelatihan pembuatan soal guru untuk memperkuat perolehan data dari teknik observasi dan teknik wawancara.

\section{Teknis Analisis Data}

Teknis analisis data yang digunakan adalah analisis data penelitian deskriptif kuantitatif, Arikunto (2010:282) data kuantitatif berupa angka-angka. Data yang sudah terkumpul melalui beberapa teknik pengumpul data, data kuantitatif diperoleh dari tabulasi kemudian dianalisis dengan cara 
mendeskripsikan data, data yang dimaksud yakni data nilai kemampuan guru di sekolah.

Penentuan pemberian nilai adalah berdasarkan adaptif, yaitu pembelajaran remedial hendaknya memungkinkan peserta didik untuk belajar sesuai dengan daya tangkap, kesempatan, dan gaya belajar masing-masing, kemudian interaktif yaitu pembelajaran remedial hendaknya melibatkan keaktifan pendidik untuk secara intensif berinteraksi dengan peserta didik dan selalu memberikan monitoring dan pengawasan agar mengetahui kemajuan belajar peserta didik, lalu berbagai metode pembelajaran dan penilaian pembelajaran remedial yaitu perlu menggunakan berbagai metode pembelajaran dan metode penilaian yang sesuai dengan karakteristik peserta didik, kemudian Pemberian umpan balik sesegera mungkin, dan berkesinambungan pembelajaran remedial dilakukan berkesinambungan dengan proses pembelajaran dan pendidik harus selalu menyediakan program remedial sesuai dengan kebutuhan. Adapun tabel penjelasan mengenai kriteria penilaian adalah sebagai berikut:

Tabel 1. Kriteria Penilaian

\begin{tabular}{|c|c|}
\hline Skor & Kriteria \\
\hline Skor 1 & Kurang Baik \\
\hline Skor 2 & Cukup Baik \\
\hline Skor 3 & Baik \\
\hline Skor 4 & Sangat Baik \\
\hline
\end{tabular}

Sumber : Data Primer (2019)

Data yang sudah terkumpul melalui data nilai observasi kemudian dianalisis dengan cara mendeskripsikan data nilai observasi kemampuan guru, yaitu sebagai berikut :

$$
\text { Rata-rata }=\sum \frac{\text { Jumlah Total Nilai }}{\sum \text { Jumlah Guru }} \times 100 \%
$$

Berdasaarkan analisis data tersebut kemudian didapatkan nilai yang menjadi hasil akhir rata-rata dari nilai observasi setiap kelas kemudian dapat dikelompokkan berdasarkan tabel sebagai berikut:

Tabel 2. Kategori Penilaian

\begin{tabular}{|c|c|}
\hline Sangat Baik & $85-100$ \\
\hline Baik & $71-85$ \\
\hline Cukup & $56-70$ \\
\hline Kurang & $\leq 55$ \\
\hline \multicolumn{2}{|c|}{ Sumber : Data Primer (2019) }
\end{tabular}

Berdasarkan tabel tersebut dapat dijelaskan bahwa rata-rata nilai yang kurang dari 55\% berada dalam kategori kurang. Rata-rata nilai antara 56-70\% berada dalam kategori cukup. Rata-rata nilai antara $71-85 \%$ berada dalam kategori baik. Rata-rata nilai antara $85-100 \%$ berada dalam kategori sangat baik.

Analisis data yang dilakukan dalam penilaian Kemampuan guru dalam kegiatan pembinaan dan penentuan kategori dilakukan untuk setiap siklus.

\section{Kriteria Keberhasilan}

Kriteria yang digunakan dalam Penelitian Tindakan Sekolah ini untuk mengukur Kemampuan guru dalam membuatt program remidial adalah jika 
kemampuan guru dalam kegiatan pembinaan dari hasil obsevasi mencapai nilai minimal $85 \%$ yaitu masuk dalam kategori sangat baik.

\section{HASIL PENELITIAN DAN PEMBAHASAN}

\section{Hasil Penelitian}

\section{Siklus I}

Berdasarkan data pada pelaksanaan siklus I, Kepala sekolah dapat melakukan analisis kekurangan dan menetapkan upaya yang harus dilakukan dalam menerapkan kegiatan pembinaan untuk meningkatkan kemampuan guru dalam menyusun program remidial dan penilaian dilakukan oleh kepala sekolah. Sehingga berdasarkan pengamatan yang dilakukan oleh Kepala sekolah saat melakukan proses pembinaan kepada guru tersebut didapatkan hasil bahwa pada saat pembinaan dalam meningkatkan kemampuan guru dalam menyusun program remidial dan penilaian dilakukan oleh Kepala sekolah adalah sebagai berikut:

Tabel 3. Hasil Kemampuan Guru dalam Menyusun Kegiatan Remidial pada Siklus I

\begin{tabular}{|c|c|c|}
\hline No. Responden & Nilai (\%) & Keterangan \\
\hline 1 & 70.83 & Cukup baik \\
\hline 2 & 66.67 & Cukup baik \\
\hline 3 & 58.33 & Cukup baik \\
\hline 4 & 75.00 & Baik \\
\hline 5 & 54.17 & Kurang Baik \\
\hline Rata-Rata & $\mathbf{6 5 . 0 0}$ & Cukup baik \\
\hline
\end{tabular}

Sumber : Hasil Penelitian, diolah (2019)

Berdasarkan data tersebut diatas dapat dijelaskan nilai masing-masing guru dengan nomor 1 memperoleh nilai $70.83 \%$ yang masuk dalam kategori cukup baik. Guru dengan nomor 2 memperoleh nilai $66.67 \%$ yang masuk dalam kategori cukup baik. Guru dengan nomor 3 memperoleh nilai 58.33\% yang masuk dalam kategori cukup baik. Guru dengan nomor 4 memperoleh nilai $75.00 \%$ yang masuk dalam kategori baik. Guru dengan nomor 5 memperoleh nilai $54.17 \%$ yang masuk dalam kategori kurang baik.

Berdasarkan hasil perolehan data tersebut didapatkan bahwa rata-rata Kemampuan Guru dalam Menyusun kegiatan remidial hanya sebesar $65.00 \%$, meskipun sudah tergolong pada kategori baik akan tetapi nilai rata-rata ini masih dirasa kurang dan perlu dilakukan perbaikan agar Kemampuan Guru dalam Menyusun program remidial.

Berdasarkan hasil perolehan persentase tentang peningkatan Kemampuan Guru dalam Menyusun program remidial dapat dijelaskan rincian perolehan persentase sesuai kategori pada tabel berikut:

Tabel 4. Rekapitulasi Hasil Kategori Kemampuan Guru dalam Menyusun Strategi dan Model Pembelajaran pada Siklus I

\begin{tabular}{|c|c|c|c|}
\hline No & Kategori & Frekuensi & Persentase \\
\hline 1 & Sangat baik & 0 & 0 \\
\hline 2 & Baik & 1 & $20 \%$ \\
\hline
\end{tabular}




\section{Lanjutan Tabel 4. Rekapitulasi Hasil Kategori Kemampuan Guru dalam Menyusun Strategi dan Model Pembelajaran pada Siklus I}

\begin{tabular}{|c|c|c|c|}
\hline No & Kategori & Frekuensi & Persentase \\
\hline 3 & Cukup & 3 & $60 \%$ \\
\hline 4 & Kurang & 1 & $20 \%$ \\
\hline & Jumlah & 5 & $100 \%$ \\
\hline
\end{tabular}

Sumber : Hasil Penelitian, diolah (2019)

Berdasarkan tabel tersebut dapat dijelaskan bahwa prosentase kategori Kemampuan Guru dalam Menyusun program remidial, guru yang mendapatkan kategori baik adalah sebanyak 1 atau sebesar 20\%. Guru yang mendapakan ketegori cukup adalah sebanyak 3 atau 60\%, kelompok guru yang mendapatkan kategori kurang baik adalah sebanyak 1 atau 20\%, dan tidak ada guru yang mendapatkan kategori cukup.

Dari hasil rekapitulasi observasi penelitian tersebut, meskipun sebagian besar kelompok sudah mendapat kategori baik, akan tetapi hasil ketuntatan ratarata kemampuan guru dalam program remidial adalah $63.33 \%$, nilai rata-rata ini masih masih belum mencapai nilai maksimal yang ditetapkan yaitu $85 \%$, dan juga masih ada beberapa guru yang mendapatkan nilai dibawah 85, untuk itu perlu adanya siklus II guna untuk memperbaiki kemampuan guru dalam Menyusun program remidial, sehingga harapan nantinya semua kelompok memperoleh nilai diatas nilai kriteria yang ditetapkan.

\section{Refleksi}

Dari hasil yang diperoleh menunjukkan kinerja guru dalam menyusun program remidial pada siklus I belum menunjukkan hasil sesuai dengan indikator kemampuan yang telah ditetapkan. Setelah diadakan refleksi terhadap hasil yang diperoleh, diputuskan untuk memperbaiki dari segi kegiatan pembinaan terutama memperjelas tentang aspek-aspek yang belum sesuai dengan indikator kemampuan yang telah ditetapkan. Dari hasil tersebut tampaknya secara umum guru dalam menyusun program remidial tidak sesuai dengan format terutama dalam hal waktu. Dari masalah tersebut, diputuskan untuk memperbaiki beberapa langkah dalam siklus I, yakni memfokuskan pada penjelasan tentang format dan aspek penilaian dalam kaitannya dengan menyusun program remidial. Langkah-langkah ini dijalankan pada siklus II dengan tetap mempertahankan kegiatan yang lain yang sudah dianggap baik. Untuk meningkatkan kesiapan guru, fasilitator memberikan kesadaran bahwa petapa penting perencanaan pembelajaran yang dibuat guru sebelum melaksanakan pembelajaran

\section{Siklus II}

Berdasarkan data pada pelaksanaan siklus II, Kepala sekolah dapat melakukan analisis kekurangan dan menetapkan upaya yang harus dilakukan dalam menerapkan kegiatan pembinaan untuk meningkatkan kemampuan guru dalam menyusun program remedial dan penilaian dilakukan oleh kepala sekolah. Sehingga berdasarkan pengamatan yang dilakukan oleh Kepala sekolah saat melakukan proses pembinaan kepada guru tersebut didapatkan hasil peningkatan 
kemampuan guru dan penilaian dilakukan oleh Kepala sekolah adalah sebagai berikut:

Tabel 5. Hasil Kemampuan Guru dalam Menyusun Program Remidial pada Siklus II

\begin{tabular}{|c|c|c|}
\hline No. Responden & Nilai (\%) & Keterangan \\
\hline 1 & 91.67 & Sangat Baik \\
\hline 2 & 87.50 & Sangat Baik \\
\hline 3 & 83.33 & Baik \\
\hline 4 & 95.83 & Sangat Baik \\
\hline 5 & 75.00 & Baik \\
\hline Rata-Rata & 86.67 & Sangat Baik \\
\hline
\end{tabular}

Sumber : Hasil Penelitian, diolah (2019)

Berdasarkan data tersebut diatas dapat dijelaskan nilai masing-masing guru dengan nomor 1 memperoleh nilai $91.67 \%$ yang masuk dalam kategori sangat baik. Guru dengan nomor 2 memperoleh nilai $87.50 \%$ yang masuk dalam kategori sangat baik. Guru dengan nomor 3 memperoleh nilai $83.33 \%$ yang masuk dalam kategori baik. Guru dengan nomor 4 memperoleh nilai $95.83 \%$ yang masuk dalam kategori sangat baik. Guru dengan nomor 5 memperoleh nilai $75.00 \%$ yang masuk dalam kategori baik.

Berdasarkan hasil perolehan data tersebut didapatkan bahwa rata-rata kemampuan guru dalam menyusun program remidial pada siklus II sebesar $86.67 \%$ yang sudah tergolong pada kategori sangat baik dan sudah mencapai hasil rata-rata maksimal $85 \%$.

Kemudian hasil perolehan persentase tentang peningkatan kemampuan Guru dalam menyusun program remidial dapat dijelaskan rincian perolehan persentase sesuai kategori pada tabel berikut:

Tabel 6. Rekapitulasi Hasil Kategori Kemampuan Guru Menyusun Program Remidial (Siklus II)

\begin{tabular}{|c|c|c|c|}
\hline No & Kategori & Frekuensi & Persentase \\
\hline 1 & Sangat baik & 3 & $60 \%$ \\
\hline 2 & Baik & 2 & $40 \%$ \\
\hline 3 & Cukup & 0 & $0 \%$ \\
\hline 4 & Kurang & 0 & $0 \%$ \\
\hline \multicolumn{2}{|c|}{ Jumlah } & 5 & $100 \%$ \\
\hline
\end{tabular}

Sumber : Hasil Penelitian, diolah (2019)

Berdasarkan tabel tersebut dapat dijelaskan bahwa kategori peningkatan Kemampuan Guru dalam menyusun program remidial, kelompok guru yang mendapatkan kategori sangat baik adalah sebanyak 3 atau sebesar $60 \%$. guru yang mendapatkan kategori baik adalah sebanyak 2 atau sebesar $40 \%$, dan tidak ada guru yang mendapatkan kategori cukup dan kategori kurang.

\section{Refleksi}

Berdasarkan hasil penelitian yang didapatkan pada tindakan siklus II, peneliti beserta guru melakukan diskusi dengan tujuan untuk melakukan refleksi terhadap pelaksanaan tindakan siklus II yang telah dilakukan. Melalui diskusi yang 
dilakukan diperoleh kesepakatan mengenai faktor keberhasilan dan kegagalan dalam pelaksanaan kegiatan pembinaan.

Setelah dilakukan tindakan penelitian pada siklus II didapatkan hasil bahwa adanya pelaksanaan kegiatan Pembinaan oleh Kepala sekolah ternyata dapat meningkatkan penyusunan program remidial, hal tersebut dibuktikan dengan nilai kemampuan guru dalam menyusun program remidial Melalui Kegiatan pembinaan pada siklus II meningkat secara signifikan dibandingkan dengan hasil yang didapatkan saat siklus I. Hal tersebut dapat dijelaskan bahwa adanya pelaksanaan pembinaan oleh Kepala sekolah telah memberi dampak positif kepada guru dengan meningkatnya kemampuan guru dalam menyusun program remidial.

Berdasarkan pada sebagian kekurangan yang masih didapatkan peneliti melakukan tindak lanjut dengan memberikan nasehat serta pengarahan kepada guru bagaimana meningkatkan menyusun program remidial dengan baik. Pemberian nasehat oleh peneliti dilakukan secara diskusi dengan guru sehingga guru juga dapat melakukan koreksi serta perbaikan dan dapat meningkatkan kemampuan guru dalam menyusun program remidial.

\section{Pembahasan}

Berdasarkan hasil penelitian yang telah dilakukan sebelumnya dengan melakukan pembinaan oleh Kepala sekolah. Kegiatan yang dilakukan diantaranya adalah dengan melakukan persiapan berupa pemberian nasehat dan masukan kepada guru dalam menyusun program remidial, serta evaluasi yang dilakukan Kepala sekolah dengan memberikan sejumlah pertanyaan terkait pengaruh pelaksanaan kegiatan pembinaan oleh Kepala sekolah sehingga diperoleh hasil penelitian pada siklus I, siklus II yang dijelaskan dalam tabel berikut:

Tabel 7. Rekapitulasi Hasil Kemampuan Guru dalam Menyusun Strategi dan Model Pembelajaran (Siklus I dan Siklus II)

\begin{tabular}{|c|c|c|c|c|}
\hline \multirow{2}{*}{ No } & \multirow{2}{*}{ Responden } & \multicolumn{2}{|c|}{ Jumlah skor } & \multirow{2}{*}{ Keterangan } \\
\cline { 3 - 4 } & & Siklus I & Siklus II & \\
\hline 1 & 1 & 70.83 & 91.67 & Meningkat \\
\hline 2 & 2 & 66.67 & 87.50 & Meningkat \\
\hline 3 & 3 & 58.33 & 83.33 & Meningkat \\
\hline 4 & 4 & 75.00 & 95.83 & Meningkat \\
\hline 5 & 5 & 54.17 & 75.00 & Meningkat \\
\hline \multicolumn{2}{|c|}{ Rata-Rata } & 65.00 & 86.67 & Meningkat \\
\hline
\end{tabular}

Sumber : Hasil Penelitian, diolah (2019)

Berdasarkan tabel tersebut dapat dijelaskan bahwa hasil Kemampuan Guru dalam Menyusun program remidial terlihat mengalami peningkatan yang signifikan. Pada Siklus 1 Kemampuan Guru dalam Menyusun program remidial adalah sebesar $65.00 \%$ yang masuk dalam kategori cukup. Penilaian pada siklus II didapatkan hasil rata-rata Kemampuan Guru dalam Menyusun program remidial adalah sebesar $86.67 \%$ yang masuk dalam kategori sangat baik, hasil tersebut meningkat dibandingkan dengan siklus I dengan peningkatan sebesar $21.67 \%$.

Sehingga dapat dinilai tindakan yang dilakukan pada siklus II sudah meningkat serta memenuhi kriteria keberhasilan yang telah ditentukan, untuk itu tidak perlu adanya perlakukan tindakan pada siklus berikutnya. Sehingga 
pelaksanaan pembinaan untuk meningkatkan kemampuan guru dalam Menyusun program pembinaan berakhir pada siklus II dan perlakuan pembimbingan lebih lanjut akan dilakukan diluar penelitian ini untuk mendapatkan kemampuan yang lebih maksimal.

\section{KESIMPULAN DAN SARAN \\ Kesimpulan}

Berdasarkan penelitian yang berjudul Meningkatkan Kemampuan Guru Dalam Membuat Program Remidial Melalui Pembinaan Guru Dengan Diskusi Kelompok di SDN Telok Jolo 3 Semester II Tahun Ajaran 2018 / 2019 yang sudah dilakukan penelitian dan didapatkan hasil kesimpulannya sebagai berikut:

1. Pada saat proses pelaksanaan kegiatan pembinaan yang dilakukan oleh kepala sekolah dinilai dapat meningkatkan kemampuan guru, hal tersebut dapat dilihat melalui hasil observasi yang dilakukan oleh peneliti meningkat secara signifikan mulai dari siklus I dengan hasil rata-rata cukup meningkat. Sehingga dapat disimpulkan bahwa adanya kegiatan pembinaan yang dilakukan oleh kepala sekolah dapat meningkatkan kemampuan guru dalam menyusun program remidial.

2. Upaya efektivitas yang dilakukan oleh kepala sekolah sebagai peneliti dalam meningkatkan kemampuan guru dalam menyusun program remidial adalah dengan memberikan kegiatan Pembinaan dan Supervisi serta nasehat kepada guru, memberikan masukan positif dan memberikan koreksi pebaikan terhadap kekurangan yang telah dilakukan oleh guru dalam perbaikan kemampuan guru dalam menyusun program remidial.

\section{Saran}

Berdasarkan hasil penelitian dan kesimpulan, peneliti dapat mengajukan beberapa saran yang dijelaskan sebagai berikut:

1. Perlu adanya kegiatan pembinaan yang berkesinambungan oleh kepala sekolah untuk dapat lebih meningkatkan kemampuan guru dalam menyusun program remidial. Sehingga diharapkan hasil yang dicapai dalam kualitas pembelajaran lebih baik dan menghasilkan peserta didik yang berkualitas.

2. Perlu adanya pengembangan kegiatan Pembinaan pada kegiatan penyusunan program remidial yang lebih baik dari segi kualitas sehingga dalam proses untuk meningkatkan mutu guru dapat lebih efektif dan efisien.

\section{DAFTAR PUSTAKA}

Arikunto, S. 2010. Prosedur Penelitian Suatu Pendekatan Praktik. Jakarta: Rineka Cipta

Fathurrohman, M dan Sulistyorini. 2012. Belajar Dan Pembelajaran Meningkatkan Mutu Pembelajaran Sesuai Standar Nasional. Yogyakarta: Teras

Hamzah B Uno. 2016 Teori Motivasi dan Pengukurannya Analisis Dibidang Pendidikan. Jakarta: PT. Bumi Aksara

Kustawan, Dedy. 2013. Analisis Hasil Belajar. Jakarta: Luxima Metro Media 
Peraturan Menteri Pendidikan Nasional Nomor 6 Tahun 2007 tentang Perubahan Permendiknas Nomor 24 Tahun 2006 tentang Pedoman Pelaksanaan Permendiknas Nomor 22 Tahun 2007 dan Permendiknas Nomor 23 Tahun 2007, Jakarta: Direktorat Jenderal Manajemen Pendidikan Dasar dan Menengah.

POERWADARMINTA. 2012. Kamus Umum Bahasa Indonesia. Jakarta: Balai Pustaka

Sanjaya, Wina. 2010. Strategi Pembelajaran Berorientasi Standar Proses Pendidikan. Jakarta : Prenada Media Group

Sugihartono, dkk. 2007. Psikologi Pendidikan.Yogyakarta: UNY Press

Sugiyono. 2014. Metode Penelitian Pendidikan Pendekatan Kuantitatif, Kualitatif, dan $R \& D$. Bandung: Alfabeta.

Sukardi. 2008. Metodologi Penelitian Pendidikan, Kompetensi dan Praktiknya. Jakarta : PT. Bumi Aksara.

SUKMADINATA. 2010. Metode Penenelitian Pendidikan. Bandung: PT Remaja. Rosdakarya 